\title{
Fulminant Hepatic Failure in Glucose-6- Phosphate Dehydrogenase (G6PD) Deficient Patients Caused by Hepatitis E Infection: A Single Disease With Different Spectrums
}

\author{
Lubna Kamani $^{1}$, Hafeezullah Shaikh ${ }^{2}$, Ajit Kumar Khemchandani ${ }^{3}$ \\ 1. Gastroenterology, Liaquat National Hospital, Karachi, PAK 2. Gastroenterology and Hepatology, National Institute \\ of Liver \& GI Diseases (NILGID) Dow University Hospital (DUH), Karachi, PAK 3. Gastroenterology, National Institute \\ of Liver \& GI Diseases (NILGID) Dow University of Health Sciences, Karachi, PAK
}

Corresponding author: Lubna Kamani, lkamani@yahoo.com

\begin{abstract}
One of the major causes of acute viral hepatitis in Pakistan is the hepatitis E virus. Virus-induced liver inflammation within sight of glucose-6-phosphate dehydrogenase (G6PD) insufficiency might be related with intricacies, for example, extremely low hemoglobin, red blood cell (RBC) destruction, renal function collapse, a decline in brain function due to severe liver disease and even demise. Despite the two diseases being widespread, their effect on understanding patient ailment has not been studied in depth. Hemolytic anemia occurs as a complication of acute hepatitis. Nevertheless, the occurrence can ascend to a large percentage of patients harboring glucose-6-phosphate dehydrogenase (G6PD) insufficiency. Although being frequent in endemic countries, there is a lack of literature in understanding the synergistic effect of hepatitis E disease and G6PD inadequacy leading to fulminant hepatic failure and increased mortality in the absence of a liver transplant facility. Here we report a case of two brothers, both having G6PD deficiency. A 19-year-old male, the elder of the two brothers, came with three days of complaints of persistent vomiting and deep jaundice. On investigation, he was found to have acute hepatitis E. During his hospital stay, he became drowsy, comatose, and subsequently expired. The second patient, his younger brother, was a 15year-old male who presented with similar history about one week after his demise. He was also managed conservatively and was subsequently discharged from the hospital.
\end{abstract}

Review began 12/02/2020 Review ended 12/24/2020 Published 12/25/2020

\section{(c) Copyright 2020}

Kamani et al. This is an open access article distributed under the terms of the Creative Commons Attribution License CC-BY 4.0., which permits unrestricted use, distribution, and reproduction in any medium, provided the original author and source are credited.
Categories: Emergency Medicine, Gastroenterology, Hematology

Keywords: hemolysis, fulminant hepatic failure, glucose-6-phosphate dehydrogenase (g6pd), acute hepatitis e

\section{Introduction}

More than 400 million people worldwide are recognized to have inherited inadequate glucose-6-phosphate dehydrogenase (G6PD) enzyme, making it the most widely recognized acquired catalyst inadequacy [1]. The frequency of G6PD insufficiency in Pakistan is about 1.8\% [2]. Hemolytic anemia occurs in 23\% of victims as the intricacy of acute hepatitis. Nevertheless, the occurrence can ascend to $70 \%$ in patients harboring G6PD insufficiency [3]. Fulminant hepatic failure includes proof of coagulation variation from the norm, generally an international normalized ratio (INR) $\geqslant 1.5$, and any level of mental transformation in a patient without prior cirrhosis and with a sickness of $<26$ weeks [4]. Despite the two diseases being widespread, understanding patients' ailments have not been accounted for and limited only to case reports [5-7].

G6PD inadequacy is an X-connected recessive inherited illness described by unusually low degrees of glucose-6-phosphate dehydrogenase (curtailed G6PD or 6PDH), an assimilation catalyst associated with the hexose monophosphate (HMP) shunt pathway, particularly significant in red blood cells (RBC) catabolism [8]. It is frequently considered and revealed as more common in males; nonetheless, heterozygous females are a more frequent genotype [9]. More than 400 diverse hereditary variations of G6PD deficiency have been counted; for 186 of them, the exact mutation is known: most are single base changes, leading to amino acid substitutions causing missense mutation [10]. Massive intravascular hemolysis with renal insufficiency, hepatic encephalopathy, and even demise has recently been noted [11]. This case report presents two patients with similar clinical manifestations and the same diagnosis but totally different outcomes. It leads to the need to investigate and identify other factors predicting outcomes in (G6PD) deficient patients infected by acute hepatitis $\mathrm{E}$.

\section{Case Presentation}

\section{Case 1}

A 19-year-old male with no known co-morbidities admitted to the emergency department with complaints of persistent vomiting and yellowish discoloration of sclera for three days. On general assessment, he was profoundly icteric. He denied any history of alcohol or over the counter drug intake. The abdominal assessment revealed a normal examination with no visceromegaly, and the rest of the examination was 
unremarkable.

Lab examinations revealed hemoglobin $(\mathrm{Hb})$ concentration of $13 \mathrm{mg} / \mathrm{dl}$ on the day of admission, white blood count (WBC) of 12900 cells $/ \mathrm{mm}^{3}$ on admission, serum total bilirubin of $27.2 \mathrm{mg} / \mathrm{dl}$, serum glutamate pyruvate transaminase (SGPT) was $6400 \mathrm{u} / 1$, and prothrombin time (PT) was 24 seconds (control 9 seconds). Hepatitis A virus immunoglobulin M (HAV IgM), hepatitis B core antibody (anti-HBc) total, hepatitis B surface antigen ( $\mathrm{HBsAg}$ ), and anti-hepatitis $\mathrm{C}$ virus (anti-HCV) were all negative, while hepatitis $\mathrm{E}$ virus (HEV) IgM came out to be reactive. The final diagnosis of severe hepatitis $\mathrm{E}$ was made, and the patient was managed accordingly.

In the days that followed, total bilirubin heightened to $65.9 \mathrm{mg} / \mathrm{dl}$ (direct fraction: $40.61 \mathrm{mg} / \mathrm{dl}$ ), and alanine aminotransferase (ALT) was $3400 \mathrm{u} / \mathrm{l}$. The hemoglobin (Hb) declined to $7.4 \mathrm{~g} / \mathrm{dl}$. PT rose to 31 seconds. The peripheral film showed macrocytes with spherocytes and rouleaux formation. Urine was reactive for hemoglobin. The plasma lactate dehydrogenase (LDH) level was $5700 \mathrm{U} / \mathrm{L}$ (range: 200 to $500 \mathrm{U} / \mathrm{L}$ ), and plasma haptoglobin was imperceptible. Retic count was 1.4. Direct anti-globulin test (DAT) and indirect antiglobulin test (IAT) were negative. The microscopic examination of blood films and antigen-based rapid diagnostic tests (RDT) for malaria were negative. Wilson's disease was excluded by normal ceruloplasmin levels and the absence of deposits of copper in a ring around the cornea on slit-lamp examination. The serum G6PD levels were less than 10\% from normal values. The patient was supervised modestly, inclusive of evading all hepatotoxins and ensuring sufficient urine output, but with progressively deteriorating Glasgow Coma Scale score, the patient was later intubated.

Later, the patient suddenly desaturated, and at the same time, he developed hematuria. He had been given fresh frozen plasma and blood transfused about two units of pack cell volume, but he was continuously deteriorating, dropping hemoglobin, and despite all aggressive measures, he ultimately expired.

\section{Case 2}

A 15 -year-old male, the younger brother of the above-mentioned patient, recently diagnosed as anti-HEV IgM positive with G6PD deficiency admitted to the emergency department with complaints of yellowish discoloration of sclera, persistent vomiting for two days, and drowsiness for one day. There was no history of alcohol or drug intake before coming to the hospital. On assessment, he was mildly icteric, abdominal assessment uncovered a non-tender abdomen with no visceromegaly, and the rest of the systemic examination was unremarkable. Lab examinations showed a hemoglobin concentration of $11.6 \mathrm{gm} / \mathrm{dl}$, WBC counts of 16300 cells $/ \mathrm{mm}^{3}$. PT of $13 \mathrm{sec}$ (control $9 \mathrm{sec}$ ). Total bilirubin concentration was $6.95 \mathrm{gm} / \mathrm{dl}$ (conjugated fraction $5.56 \mathrm{mg} / \mathrm{dl}$ ), alanine aminotransferase of $1374 \mathrm{u} / 1$. Serum amylase was 65 . The urine detailed report was normal. Blood culture and sensitivity were negative. The ultrasound abdomen was normal. The patient was managed conservatively in the intensive care unit. He got better the next day; his total bilirubin decreased from the previous value to $5.4 \mathrm{gm} / 1$, prothrombin time was $11 \mathrm{~s}$. Therefore he was shifted to the ward. On the third day, he was discharged home.

\section{Discussion}

Meagre hemolysis related to diminished red blood cell viability might be routinely observed with virusinduced liver inflammation yet is rarely a clinical consequence [12, 13]. Even so, when virus-induced liver inflammation happens in G6PD-insufficient patients, hemolysis might be serious [13, 14]. In our case report, the first patient had serious hemolysis occurring in the vasculature as proven by a fall in hemoglobin, raised bilirubin in the blood, hemoglobin excretion in urine, imperceptible plasma haptoglobin degrees, and heightened serum lactate dehydrogenase level. The existence of extremely raised serum bilirubin levels in patients with viral-induced liver inflammation and G6PD insufficiency has been recently revealed [15-18]. The effects of G6PD insufficiency on cases with hepatitis A infection was evaluated by Gotsman and Muszkat in a case-control study [19]. Significant hemolysis in G6PD-lacking people is normally accelerated by the introduction of exclusive drugs. Nonetheless, as for this situation, virus-induced liver inflammation might hasten substantial hemolysis even without the admission of such medications [13, 18]. When G6PD lack is alleged, therapy with drugs causing hemolysis ought to be evaded in light of the fact that it might also exacerbate hemolysis [20].

The system of hemolysis is anticipated to happen through diminished degrees of reduced glutathione in erythrocytes. [12]. Declined glutathione levels could transpire from the amassing of oxidative agents because of hepatic ailment and give rise to expanded hemolysis within sight of G6PD lack. Despite the significant bilirubin levels in these cases, the foreboding is mostly identified with the seriousness of liver injury [15].

HEV disease is communicated through the feco-oral course. At the same time, in contrast to other enteric operators, it doesn't commonly spread from contaminated people to their nearby contacts.

In the above two cases, both brothers acquired HEV infection, and both had G6PD deficiency. The elder brother developed fulminant hepatic failure, hemolysis and ultimately died. While the younger sibling did not develop these complications, he became better and discharged home. 


\section{Conclusions}

In patients with severe virus-induced liver inflammation and unexplained low hemoglobin levels with heightened bilirubin concentrations, hemolysis in vasculature should be thought of and researched as it could be a prognostic factor in these patients.

\section{Additional Information \\ Disclosures}

Human subjects: Consent was obtained by all participants in this study. Conflicts of interest: In compliance with the ICMJE uniform disclosure form, all authors declare the following: Payment/services info: All authors have declared that no financial support was received from any organization for the submitted work. Financial relationships: All authors have declared that they have no financial relationships at present or within the previous three years with any organizations that might have an interest in the submitted work. Other relationships: All authors have declared that there are no other relationships or activities that could appear to have influenced the submitted work.

\section{References}

1. Cappellini MD, Fiorelli G: Glucose-6-phosphate dehydrogenase deficiency. Lancet. 2008, 371:64-74. 10.1016/S0140-6736(08)60073-2

2. Moiz B: A review of G6PD deficiency in Pakistani perspective . J Pak Med Assoc. 2013, 63:501-503.

3. Fousekis FS, Mitselos IV, Christodoulou DK: Extrahepatic manifestations of hepatitis E virus: an overview . Clin Mol Hepatol. 2020, 26:16-23. 10.3350/cmh.2019.0082

4. Polson J, Lee WM: AASLD position paper: the management of acute liver failure . Hepatology. 2005, 41:1179-1197.

5. Tomar LR, Aggarwal A, Jain P, Rajpal S, Agarwal MP: Acute viral hepatitis E presenting with haemolytic anaemia and acute renal failure in a patient with glucose-6-phosphate dehydrogenase deficiency. Trop Doct. 2015, 45:245-246. 10.1177\%2F0049475514559959

6. Monga A, Makkar RP, Arora A, Mukhopadhyay S, Gupta AK: Case report: Acute hepatitis E infection with coexistent glucose-6-phosphate dehydrogenase deficiency. Can J Infect Dis. 2003, 14:230-231. 10.1155/2003/913679

7. Ahmad BS, Ahmad A, Jamil S, Abubakar Mohsin Ehsanullah SA, Munir A: Severe haemolysis and renal failure precipitated by hepatitis E virus in G6PD Deficient patient: a case report. J Pak Med Assoc. 2018, 68:1397-1399.

8. Harcke SJ, Rizzolo D, Harcke HT: G6PD deficiency: an update. JAAPA. 2019, 32:21-26. 10.1097/01.JAA.0000586304.65429.a7

9. Glucose-6-Phosphate Dehydrogenase Deficiency 2020. (2020). Accessed: 25th September, 2020: https://rarediseases.org/rare-diseases/glucose-6-phosphate-dehydrogenase-deficiency..

10. Luzzatto L, Nannelli C, Notaro R: Glucose-6-phosphate dehydrogenase deficiency. Hematol Oncol Clin North Am. 2016, 30:373-393. 10.1016/j.hoc.2015.11.006

11. Aggarwal R: Clinical presentation of hepatitis E. Virus Res. 2011, 161:15-22. 10.1016/j.virusres.2011.03.017

12. Pitcher CS, Williams R: Reduced red cell survival in jaundice and its relation to abnormal glutathione metabolism. Clin Sci. 1963, 24:239-252.

13. Kattamis CA, Tjortjatou F: The hemolytic process of viral hepatitis in children with normal or deficient glucose-6-phosphate dehydrogenase activity. J Pediatr. 1970, 77:422-430. 10.1016/S0022-3476(70)80010-5

14. Chau TN, Lai ST, Lai JY, Yuen H: Haemolysis complicating acute viral hepatitis in patients with normal or deficient glucose-6-phosphate dehydrogenase activity. Scand J Infect Dis. 1997, 29:551-553. 10.3109/00365549709035892

15. Clearfield HR, Brody JI, Tumen HJ: Acute viral hepatitis, glucose-6-phosphate dehydrogenase deficiency, and hemolytic anemia. Arch Intern Med. 1969, 123:689-691. 10.1001/archinte.1969.00300160079012

16. Monga A, Makkar RP, Arora A, Mukhopadhyay S, Gupta AK: Case report: acute hepatitis E infection with coexistent glucose-6-phosphate dehydrogenase deficiency. Can J Infect Dis Med Microbiol. 2003, 14:230231. $10.1155 / 2003 / 913679$

17. Morrow RH, Jr., Smetana HF, Sai FT, Edgcomb JH: Unusual features of viral hepatitis in Accra, Ghana . Ann Intern Med. 1968, 68:1250-1264. 10.7326/0003-4819-68-6-1250

18. Salen G, Goldstein F, Haurani F, Wirts CW: Acute hemolytic anemia complicating viral hepatitis in patients with glucose-6-phosphate dehydrogenase deficiency. Ann Intern Med. 1966, 65:1210-1220. 10.7326/00034819-65-6-1210

19. Gotsman I, Muszkat M: Glucose-6-phosphate dehydrogenase deficiency is associated with increased initial clinical severity of acute viral hepatitis A. J Gastroenterol Hepatol. 2001, 16:1239-1243. 10.1046/j.14401746.2001.02611.x

20. Bunn HF: Hemolytic anemias and acute blood loss . Harrison's Principles of Internal Medicine. McGraw-Hill, New York; 2001. 681-692. 